\title{
Managing Risks in Academic Entrepreneurship: The Case of SiFAR
}

\author{
Mohar Yusof \\ Universiti Tun Abdul Razak \\ ymohar@unirazak.edu.my \\ Leilanie Mohd Nor \\ Taylor's Business School \\ leilanie.mohdnor@taylors.edu.my
}

\begin{abstract}
The main purpose of this case study is to examine the implementation and commercialization process of Simplified Financial and Recordkeeping (SiFAR) solution, a cloud-based cash flow management solution for micro and small businesses. Background of the company and entrepreneurial academics who initiated the idea and business, and the starting up process is described. The technology adoption life cycle model and the concept of crossing the chasms are used to describe the adoption rate of the solution. A pilot project was used to test the prototype and validate several features of the solution. The social scientists and entrepreneurs found a critical success factor for technology commercialization, which is managing risk. The most important factor in managing risk is to confirm demand for the solution and the willingness to pay. Hence, funds and capital need to be focused on managing risks in order for the entrepreneurial endeavor to be successful.
\end{abstract}

Keywords: Cash Flow Management, Micro and Small Business, Technology Commercialization, Technology Adoption Life Cycle Model, Managing Risk

\section{Introduction}

This case is developed as a basis for academic discussion related to the areas of entrepreneurship, innovation, technology commercialization and market adoption. It does not illustrate either effective or ineffective handling of any business or management situation. It is based on qualitative data and actual learning experience of the authors who are the entrepreneurial academics. It should not be viewed as a typical business case, but rather an insightful and elucidation of what we expect the students in a business management and entrepreneurship degree program to understand, appreciate and demonstrate when they review, analyze, and discuss the issues and challenges faced by a technology start-up in managing risks and validating a business model in a highly competitive environment.

On $17^{\text {th }}$ September 2015 at The Royale Chulan Hotel, Kuala Lumpur, the go-to-market strategy began with the soft launch of the Simplified Financial and Recordkeeping (SiFAR) solution. It was exhibited to the participants of an Islamic Finance Forum. It was developed based on research and observation on the needs and requirements to generate growth and enhance sustainability of micro and small businesses. 


\section{SiFAR}

\subsection{Starting Up SiFAR}

SiFAR was created with internal investment of the parent company, kCommerce (M) Sdn Bhd, which was owned by Mohd Noor Ismail and Noor Ashikin (refer to Appendix-A for their brief profiles). The idea and decision to build SiFAR was made after numerous attempts by the founders to collaborate with several agencies to build a Big Data repository on family businesses and family controlled medium-sized to large enterprises did not get the response they had hoped for.

They took the risks to develop SiFAR with the aspiration to assist micro and small businesses and provide business analytics to these enterprises. The strategic plan was to develop this project into a research house capable of doing not only descriptive analytics but also predictive and prescriptive analytics on the business health of small firms as well as to examine industry trends and patterns, particularly industries where small businesses were the majority.

In October 2015, after the soft launch, the management team secured a pilot project with a development bank to train 300 of its business financing clients on cash flow and record management and exposed them to the use of SiFAR. Over a period of 9 weeks, the team conducted 9 sessions and trained 95 clients (out of the targeted 300 clients, only 95 micro enterprise owners turned up for the training).

Through the pilot project, the entrepreneurs found that most micro and small businesses had a similar pain and pattern whereby they were unable to manage their cash flows efficiently and effectively which led to low profitability or losses, hence, unable to secure investments for growth or business loans from development and commercial banks. When they did secure a loan, they were unable to repay the loan.

It was also found that there was a need to simplify the cash flow management system because majority of entrepreneurs lacked of or did not have accounting knowledge and the ability to handle any complex accounting software.

As part of the collaborative agreement with the bank, the clients were given free subscription for one year. A report was submitted and presented to the bank's Business Financing Department in December 2016. From the analysis of the registrants, logins and active use of the system, it was found that only $13 \%$ of the registrants actively used the system during the pilot project period (refer to Figure 1 in Appendices).

Unfortunately, the Business Financing Department was unable to make a decision on whether to request and encourage its clients to use SiFAR even though there was no issue with regards to the solution. It was validated as an easy-to-use solution and capable in solving cash flow and financial records management of micro and small businesses. However, because only $13 \%$ of the participants used the system, the bank officers argued that their borrowers might not use the system even if it was imposed on them.

The founders described the technology adoption and the concept of crossing the chasm to the bank officers in the report but they failed to understand the concept and unwilling 
to provide the resources and support to increase the number of early majority (refer to Figure 2 in Appendices). On the part of the startup, it did not have the financial and human resources to communicate and meet with the entire pilot project participants to get them to use the system.

\subsection{Obtaining Funding}

With the bank hesitating and reluctant to encourage the use of SiFAR on its borrowers, the founders had to decide and take the risks and courage to market SiFAR more aggressively in the open market. The management decided to seek funding in order to recruit sales, marketing and customer relationship management staff. A marketing budget was also needed to re-brand the trademark, execute the sales and marketing strategies to create awareness of the brand and to strategically position the solution to outcompete its close competitors and substitutes.

As part of meeting a funding agency's requirement for a pre-commercialization grant application, a subsidiary called BinaPavo Data Intelligence Sdn Bhd (BDISB) was incorporated on 4 January, 2016. In March 2016, BDISB was successful in the grant application processed and awarded a grant worth RM500,000 subject to meeting the agreed milestones. 7 new personnel were immediately recruited on 1 April, 2016.

The list of personnel recruited included:

1) 1 Administration \& HR Manager

2) 1 Senior Executive, Marketing

3) 2 CRM Executives

4) 2 Sales Executives

5) 1 Technical Executive

It was believed that the major challenge in the revenue generation activity was the Sales Executives were fresh graduates and lack of sales experience and confidence in engaging with clients on the ground. Another key major challenge was the inability to find a full-time, experienced and suitable Sales Manager. Due to these constraints, a decision was made to outsource to an independent marketing company the development of marketing collaterals and materials as well as execute several strategic communication initiatives.

With the sales, marketing and CRM team, efforts were undertaken to market and sell more aggressively compared to before April 2016. However, activities were hindered in the fasting month in June and 'Aidil-Fitri in July since the main segment of the target market was mainly Malay, Bumiputera and Muslim owned micro and small businesses in the Klang Valley, particularly in Shah Alam, Petaling Jaya, Klang and Kuala Lumpur.

It was thought that another key segment was banks and funding agencies which were interested in allowing a third party to act as an intermediary to monitor the financial performance of its borrowers as well as provide real-time and continuous reporting. Nevertheless, based on the engagement with the development bank (the pilot project) and a commercial bank, it seemed that banks were more interested in the transformation 
and integration of its banking system and these initiatives required the technology and service providers to acquire approval from Bank Negara Malaysia independently.

\section{Data Presentation and Analysis}

\subsection{Business Development Activities}

Business development activities were aimed at establishing strategic relationships and alliances with other organizations. In this aspect, the strategy was to leverage on the expertise, technologies or other intellectual properties of business partners and collaborators to expand the capacities for identifying, researching, analyzing and bringing to market businesses solutions and products.

\subsubsection{Application for Mosques}

One of the solution development initiatives was to develop an accounting system for mosques. Through a collaboration with an accounting and audit firm which had been involved in auditing the accounts of majority of mosques in the Federal Territory and Selangor, it was identified that most mosques had difficulties in recording their donation transactions and managing their assets and liabilities. SiFAR could be replicated and customized to be able to manage mosques' assets and liabilities. The development of the system did not materialize because the business partner was unwilling to invest in developing the prototype.

\subsubsection{Collaboration with a Consulting and Training Firm}

The company was approached by a consulting and training firm which was interested in supplying mobile Point-on-Sale system and mobile payment systems. The firm owners wanted to collaborate because they had a community of merchants who required a simple cash flow and record management system. The advisory services which could be offered by BDISB could also help to enhance the capabilities of the firm's merchants and business community. Together with the firm, BDISB approached a university to offer training and solutions to the university's students. However, the relationship with the consulting firm was discontinued because the people running the consulting firm had other businesses and was busy running their businesses. In addition, they also felt that they did not really need SiFAR for their merchants and customers.

\subsubsection{Engagement with a Large Co-operative}

BDISB approached a large co-operative with many small co-operatives under its wings. After a few meetings with the President of the co-operative, followed by a presentation on the $12^{\text {th }}$ of July, 2016, the matter was handed over to the co-operative's Chief Technology Officer and Head of IT. However, the Chief Technology Officer preferred to adopt a system which had already fulfilled the functionalities required for small cooperatives, thus, SiFAR was not considered.

\subsubsection{Engagement with a Commercial Bank's Digital Department}

SiFAR was also presented to the Head of Digital Department of a commercial bank. The Head was looking for a fintech solution and wanted to find out whether SiFAR could be with the bank's system. However, in order to secure any collaboration, BDISB was urged to get the approval from Bank Negara Malaysia.

\subsubsection{Collaboration with Bizlah}

Bizlah's founder, Khairul Anwar, approached us in search of a partner to organize an event related to business finance and solutions titled Entrepreneur Financial Expo (EFE) 
in early November 2016. Bizlah was a business directory company with a database of over 28,000 businesses and had done several events to help start-ups and entrepreneurs in acquiring knowledge for business financing and solutions. However, due to lukewarm response for the Expo, the collaboration was discontinued.

\subsubsection{Engagement with the Centre of Entrepreneur Development (CED) of a Micro-Financing Agency}

BDISB was invited to apply to the CED to be one of its entrepreneurship panels of consultants. A presentation was delivered to the CED in June 2016. Unfortunately, BDISB was not chosen. In July and August 2016, the company's founder started the relationship with the IT Department of the agency, however, further efforts were stopped when the grant obtained by BDISB was discontinued because BDISB did not meet the first quarter's sales milestone of RM 70,000 revenue.

\subsection{Marketing Activities}

Marketing activities were focused on creating brand awareness and promoting SiFAR as a simplified cash flow and record management solution. Besides that, the company wanted to highlight the unique selling point that BDISB was not just providing a financial solution but also advisory services to assist users to grow and sustain their businesses.

To strategically position the brand and solution, a professional marketing firm was selected since it had the experience in implementing strategic marketing and communication for established brands and organizations. The marketing firm produced the marketing collaterals to promote SiFAR which included social media content, promotional video production, bunting, brochure and booth displays.

An important initiative was undertaken to re-brand the trademark. The founders wanted to create a professional and fresh new look for SiFAR in order to target younger group of business owners and start-ups as well as not to confine and limit users to a particular race only.

\subsubsection{Social Media Content}

Realizing the importance of online presence, BDISB established its own website. The idea of SiFAR's website was not only to enable potential users to subscribe and acquire more information and knowledge about the solution but to also serve as a platform to provide advices to blog readers about the importance of managing their finances and cash flows. Other than that, the marketing personnel engaged users and followers via Facebook with constant posts of smart quotes and financial advices, and also to connect with potential new subscribers.

\subsection{Human Resource Planning}

The founders believed that having the right employees could support them to alleviate the company's potential in the market. Therefore, they started to recruit and form a team of young staff, majority were fresh graduates. In order to equip them with necessary knowledge, skills and abilities; the founders provided them with training on their specific roles and responsibilities. By May 2016, BDISB had 9 people in the team assigned to specific roles. 


\subsubsection{Staff Recruitment}

Almost half the budget from the grant was meant for staff salaries. The personnel were organized and structured into:

- Management \& Administration (1 manager)

- Marketing (1 staff)

- Sales (2 staffs)

- Customer Relationship Management (2 staffs)

- Technical (3 staffs)

\subsection{Sales Activities}

The sales activities had been mainly focused on engaging, building relationships and acquiring new users. Throughout April to August 2016, two approaches were used - (1) direct engagement with individual business owners, and, (2) building relationships and partnerships with entrepreneurship and business-related associations, clubs and government agencies. These two approaches were combined with training sessions.

For the first approach i.e. direct engagement with individual business owners, one-toone training was usually done at our office. It was seldom that new users wanted their training to be done at their premises. This approach had been very effective to the users since personalized attention was provided and the users learnt how to use the system very quickly. However, it was very difficult to acquire interested and willing business owners.

Many Malay, Bumiputera and Muslim business owners did not place priority on cash flow and record management. Most common reasons given were they lacked time since majority was still running their businesses on their own and if they had workers; normally they had only a few. Secondly, they were still grappling with doing sales and making ends meet. Thirdly, some preferred using Excel because they felt it was free.

The founders realized it will take some time to create awareness and educate the market on the benefits and the unique selling point of SiFAR. Hence, the second approach of building relationships with entrepreneurship and business-related associations, clubs and government agencies. Several events and activities were participated which were organized by:

- Kelab Usahawan Selangor (KuSEL), Bangunan UMNO, Seksyen 14, Shah Alam

- Malaysian Association of ASEAN Young Entrepreneurs (MAAYE)

- Global Entrepreneurship Movement (GEM)

- Malaysian Global Innovation \& Creativity Centre (MaGIC)

- Keusahawanan dan Ikhtisas Wanita (KIW)

Training programs were organized and delivered free of charge to participants of the following associations and agencies:

- Persatuan Sahabat Usahawan Malaysia (PSUM)

- Persatuan Usahawan Bumiputera Malaysia (PUBM)

The main challenge faced with associations and agencies was the slow process of decision making. There were a few training programs which we had planned with the 
associations in May 2016 were cancelled at the last minute and postponed because of the fasting and Aidil-Fitri months in June and July 2016.

Starting September onwards, the team attempted on a third approach which was to organize training programs for students in higher education institutions such as universities, polytechnics and community colleges and specifically targeting students who had started micro and small businesses. The team felt that students and graduate entrepreneurs as well as educators were the right profile to target as SiFAR users and promoters.

\subsubsection{Exhibitions}

Another sales activity conducted was to exhibit SiFAR at events and exhibitions such SME Solution Expo 2016 and ITX Asia 2016, SME Economic Conference 2016, Selangor International Expo 2016 and others. With the booth set and kit were produced, the sales and marketing would be able to participate in these exhibitions. However, due to financial constraint and discontinuance of the grant, BDISB was only able to participate in the SME Solution Expo 2016 at Kuala Lumpur Convention Centre. However, the crowd who attended the Expo was below expectation, hence, it did not help the company to generate many new users

\section{Conclusion and Discussion: SiFAR's Future}

Efforts were made to engage associations and related agencies dealing with micro and small businesses but these institutions are highly bureaucratic and decisions had to go through several levels. The entrepreneurs did not have high level connections to get decisions to be made faster and in their favour. In September 2016, the decision was made to organize training and advisory programs and use the pricing strategy of charging RM500 subscription fees upon the signing up of these participants in the training programs.

In December 2016, the entrepreneurs came to a crossroad and had to slow down its operations to manage risks. At this stage, the management decided to cut its head count to control and reduce overheads. At this point, they realized that the most important factor in managing risk is to focus resources and capital on confirming demand for the solution and the users' willingness to pay in order for the entrepreneurial endeavor to be successful. With sufficient resources, capital and support, the business could have been grown to benefit and assist many micro and small businesses (refer Figure 3 in Appendix B). 


\section{Appendix A: Directors' Profiles}

\begin{tabular}{|c|c|}
\hline $\begin{array}{l}\text { Directors / Shareholders/ } \\
\text { Kev Management }\end{array}$ & Qualification / Experience \\
\hline Noor Ashikin & $\begin{array}{l}\text { Education } \\
\text { She has a Ph.D. in Management (by Research) (2014) } \\
\text { whereby in her doctoral thesis, she introduced the } \\
\text { "Decision Making Process for New Venture in Family } \\
\text { Business" theory and model. She earned her MBA in } \\
\text { 2003, and graduated from Michigan State University, } \\
\text { East Lansing, MI, USA with a BA in } \\
\text { Telecommunications in } 1996 \text {. } \\
\text { Professional Experience } \\
\text { She has more than } 15 \text { year's managerial experience in } \\
\text { large companies. During } 1997 \text { - 2005, she started her } \\
\text { career as a Project Executive with Malaysia Airlines and } \\
\text { was involved with the migration from Subang Airport to } \\
\text { KLIA. Ashikin, then moved on to DRB-HICOM where } \\
\text { she was the Project Manager for the OSS Implementation } \\
\text { project involving more than } 30 \text { consultants under her } \\
\text { purview. She was also the key management team for a } \\
\text { large project involving IT and IS implementation in } 4 \\
\text { states throughout Malaysia. Since } 2010 \text {, she has trained } \\
\text { more than } 800 \text { entrepreneurs, namely through the SUS } \\
\text { (Skim Usahawan Siswasah) and CIMB BEST } \\
\text { (Bumiputera Entrepreneur Skill Transformation) } \\
\text { programs. She has experience in designing the } \\
\text { entrepreneurship curriculum for tertiary level as well as } \\
\text { for short and long-term entrepreneurship development } \\
\text { programs for corporate clients. }\end{array}$ \\
\hline Mohd Noor Ismail & $\begin{array}{l}\text { Education } \\
\text { He has a Ph.D. in Management (by Research) in which he } \\
\text { studied the organizational antecedents of academic } \\
\text { entrepreneurship. In addition, he holds the Malaysian } \\
\text { Institute of Management - Certified Professional } \\
\text { Intellectual Property Manager (MIM-CPIPM) } \\
\text { certification and a Certified Financial Planner (CFP). } \\
\text { Professional Experience } \\
\text { Ismail is the second generation of a family business. With } \\
24 \text { years entrepreneurial and managerial experience } \\
\text { gained in start-ups and growing businesses coupled with } \\
\text { his scholarly and professional work in the academic } \\
\text { fields of family business, entrepreneurship, strategy and } \\
\text { financial planning, he has developed the aptitude and } \\
\text { competencies as a business strategist, advisor, consultant, } \\
\text { coach and trainer. } \\
\text { He was engaged as a consultant in 2007-2008 to study the } \\
\text { development of Agropolis in Serdang. } \\
\text { A recent engagement is as an industry expert for the } \\
\text { CIMB Bumiputera Vendor Development programme. He } \\
\text { has trained no less than } 800 \text { budding and nascent } \\
\text { entrepreneurs on business and financial planning. }\end{array}$ \\
\hline
\end{tabular}




\section{Appendix B: Figures}

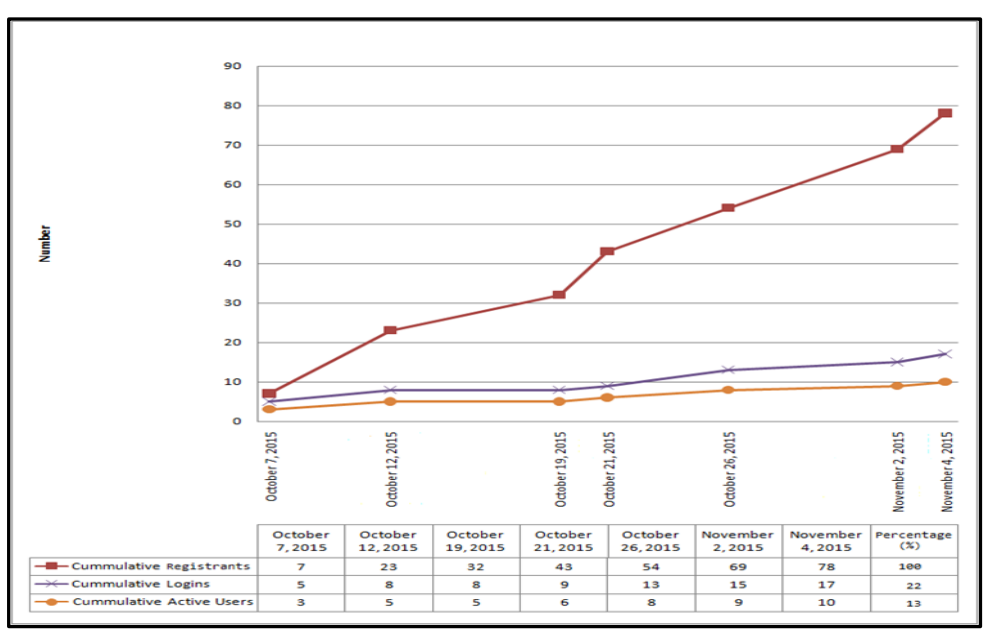

Figure 1: Number of Registrants, Logins and Active Users During the Pilot Project

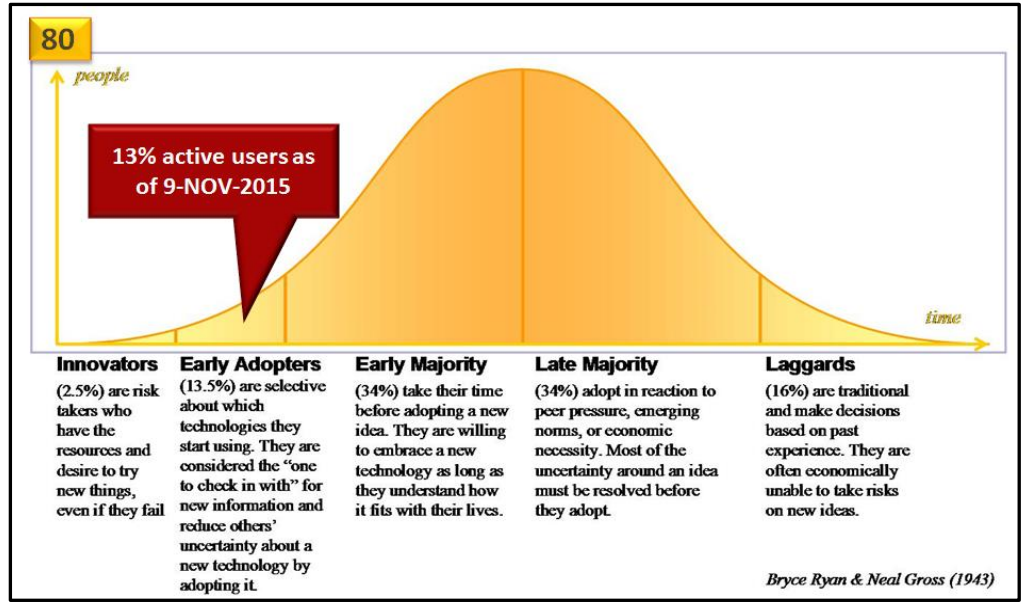

Figure 2: SiFAR's Adoption Rate During the Pilot Project

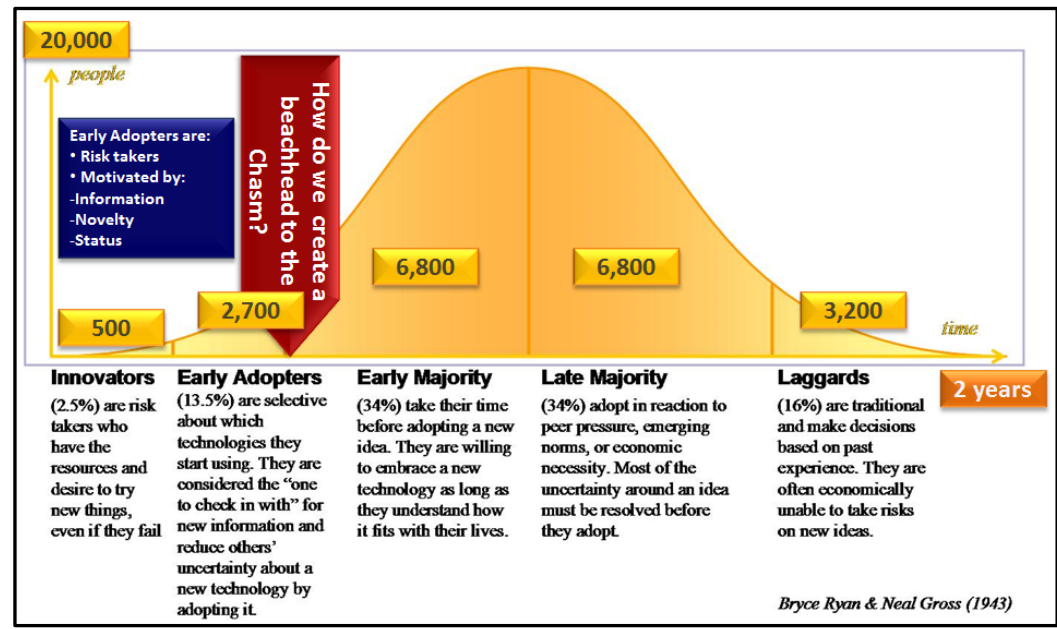

Figure 3: Crossing the Chasm 